\title{
Description of Leifsonia kafniensis sp. nov. and Leifsonia antarctica sp. nov.
}

Correspondence

S. Shivaji

shivas@ccmb.res.in

\author{
Pavan Kumar Pindi,† K. Hara Kishore,† G. S. N. Reddy and S. Shivaji \\ Centre for Cellular and Molecular Biology, Uppal Road, Hyderabad 500 007, India
}

The genus Leifsonia was originally described by Evtushenko et al. (2000) and its description was emended by Reddy et al. (2008). The genus includes bacteria that are Grampositive, non-spore-forming, rod-shaped (or filamentous), obligately aerobic and catalase-positive. The cell-wall peptidoglycan is of the $\mathrm{B}$ type and contains 2,4-diaminobutyric acid as the diamino acid. MK-11 is the major menaquinone. Phosphatidylglycerol and diphosphatidylglycerol are the principal phospholipids and the major fatty acids are anteiso- $\mathrm{C}_{15: 0}$, anteiso- $\mathrm{C}_{17: 0}$ and iso- $\mathrm{C}_{16: 0}$. The $\mathrm{G}+\mathrm{C}$ content of the DNA ranges from 66 to $73 \mathrm{~mol} \%$. At the time of writing, 11 species have been described (Evtushenko et al., 2000; Leifson, 1962; Davis et al., 1984; Suzuki et al., 1999; Reddy et al., 2003; Qiu et al., 2007; Reddy et al., 2008; Dastager et al., 2008, 2009). Of the 11

†These authors contributed equally to this work.

The GenBank/EMBL/DDBJ accession numbers for the 16S rRNA gene sequences of strains KFC-22 ${ }^{\top}$ and $\mathrm{SPC}-20^{\top}$ are $\mathrm{AM} 889135$ and AM931710, respectively.

$16 \mathrm{~S}$ rRNA gene sequence similarities of strains $\mathrm{KFC}-22^{\top}$ and SPC- $20^{\top}$ with respect to closely related strains are available as supplementary material with the online version of this paper. reported species, four (Leifsonia rubra, Leifsonia aurea, Leifsonia ginsengi and Leifsonia pindariensis) are psychrotolerant, having a minimum growth temperature of 0 $4{ }^{\circ} \mathrm{C}$; the rest are mesophilic. In the present study, two novel psychrotolerant species are described. The strains (designated KFC- $22^{\mathrm{T}}$ and $\mathrm{SPC}-20^{\mathrm{T}}$ ) representing these two novel species were isolated from two different cold habitats, namely the Kafni glacier of the Himalayas and a sediment from Antarctica, and were characterized using a polyphasic taxonomic approach.

Strain KFC- $22^{\mathrm{T}}$ was isolated from a soil sample collected close to the Kafni glacier, at an altitude of $3500 \mathrm{~m}$ in the Himalayan mountain ranges in India. Strain SPC- $20^{\mathrm{T}}$ was isolated from a spade core sediment from the Antarctic Ocean near the Larsemann Hill area $\left(69^{\circ} 21.950^{\prime} \mathrm{S} 76^{\circ}\right.$ $06.296^{\prime}$ E). A sample of approximately $200 \mathrm{mg}$ was suspended in $5 \mathrm{ml} 0.9 \% \mathrm{NaCl}$, subjected to shaking at 3000 r.p.m. for $1 \mathrm{~h}$ at room temperature, allowed to settle and plated $(100 \mu \mathrm{l})$ either on Luria-Bertani agar (for KFC$22^{\mathrm{T}}$ ) or nutrient agar (for SPC-20 $0^{\mathrm{T}}$ ) (Shivaji et al., 2005). On the basis of colony morphology, two yellow-pigmented strains $\left(\mathrm{KFC}-22^{\mathrm{T}}\right.$ and $\mathrm{SPC}-20^{\mathrm{T}}$ ) were purified and main- 
tained on nutrient agar plates (containing $0.3 \%$ beef extract, $0.5 \%$ peptone, $0.8 \%$ sodium chloride and $1.5 \%$ agar). Morphology was studied using light microscopy and transmission electron microscopy as described previously (Reddy et al., 2006) and motility was assessed on $0.4 \%$ nutrient agar plates. Growth, biochemical characteristics (Lányí, 1987; Smibert \& Krieg, 1994), carbon assimilation and the sensitivity of the cultures to different antibiotics were determined by using previously described methods (Reddy et al., 2004). Biochemical characteristics were determined using the Hi25 Enterobacteriaceae identification kit (catalogue no. KB003; Himedia) and parts A, B and $\mathrm{C}$ of the HiCarbohydrate kit (catalogue no. KB009; Himedia), according to the manufacturer's protocols.

For quantitative analysis of whole-cell fatty acids, cells of KFC- $22^{\mathrm{T}}$ and SPC- $20^{\mathrm{T}}$ were grown on tryptic soy agar medium (Reddy et al., 2008) at $25^{\circ} \mathrm{C}$ for 2 days and analysed using the Sherlock Microbial Identification System (MIDI), according to the protocols described by Agilent Technologies. Lipids and pigments were extracted and analysed as described previously (Reddy et al., 2007). Peptidoglycan and cell-wall sugars were prepared and analysed according to the method of Komagata \& Suzuki (1987). Isoprenoid quinones were extracted according to the method of Collins et al. (1977) and were separated using HPLC with an isocratic solvent system consisting of methanol/isopropyl ether $(3: 1)$ (Tamaoka et al., 1983; Tamaoka, 1986).

DNA from strains $\mathrm{KFC}-22^{\mathrm{T}}$ and $\mathrm{SPC}-20^{\mathrm{T}}$ was isolated according to the method of Marmur (1961) and the 16S rRNA gene was PCR-amplified and sequenced as described previously (Reddy et al., 2000). The almost-complete sequences (1518 and $1516 \mathrm{nt}$ for $\mathrm{KFC}-22^{\mathrm{T}}$ and SPC- $20^{\mathrm{T}}$, respectively) of the $16 \mathrm{~S}$ rRNA genes were aligned with closely related sequences belonging to the genus Leifsonia, using Clustal W (Thompson et al., 1994). Pairwise evolutionary distances were computed using the DNADIST program with Kimura's two-parameter model (Kimura, 1980). Phylogenetic trees were constructed using four different tree-making algorithms, namely neighbour joining, minimum evolution, the unweighted pair group method with arithmetic averages and maximum parsimony, by using the MEGA3 software package (Kumar et al., 2004). Bootstrap analysis, based on 1000 replicate datasets, was performed to assess stability among the clades recovered in the phylogenetic tree.

Strains KFC- $22^{\mathrm{T}}$ and SPC $-20^{\mathrm{T}}$ were assigned to the genus Leifsonia on the basis of characteristics described for the genus Leifsonia (Evtushenko et al., 2000; Reddy et al., 2008). Both isolates consisted of Gram-positive, catalasepositive, curved rods that contained 2,4-diaminobutyric acid in the peptidoglycan, had MK-11 as the major menaquinone, contained phosphatidylglycerol and diphosphatidylglycerol as the polar lipids and had high levels of fatty acids anteiso- $\mathrm{C}_{15: 0}$, anteiso- $\mathrm{C}_{17: 0}$ and iso- $\mathrm{C}_{16: 0}$. In addition, the BLAST sequence similarity results, based on
$16 \mathrm{~S}$ rRNA gene sequences, also supported the affiliation of KFC- $22^{\mathrm{T}}$ and SPC- $20^{\mathrm{T}}$ to the genus Leifsonia (Evtushenko et al., 2000; Suzuki et al., 1999; Reddy et al., 2008). The two strains shared a base-to-base 16S rRNA gene sequence similarity of $97.7 \%$ (Supplementary Table S1, available in IJSEM Online) and a DNA-DNA relatedness of approximately $10 \%$. They also exhibited many phenotypic differences (Table 1), supporting their assignment to separate novel species. Strains $\mathrm{KFC}-22^{\mathrm{T}}$ and $\mathrm{SPC}-20^{\mathrm{T}}$ exhibited 16S rRNA gene sequence similarity of 95.0$98.0 \%$ with respect to representatives of recognized species of the genus Leifsonia (Supplementary Table S1). The other phylogenetically related genera are Subtercola $(96.0 \%$ sequence similarity) (Männistö et al., 2000), Okibacterium (96.0-97.0\%) (Evtushenko et al., 2002), Salinibacterium (96.0\%) (Han et al., 2003), Rhodoglobus (95.0-96.0\%) (Sheridan et al., 2003), Plantibacter (96.0-97.0\%) (Behrendt et al., 2002), Agrococcus (96.0-97.0\%) (Groth et al., 1996) and Agreia (96.0-97.0\%) (Evtushenko et al., 2001). Although the $16 \mathrm{~S}$ rRNA gene sequence similarities were high with respect to some members of these genera, phylogenetic analyses (Fig. 1) showed that the two strains should be assigned to the genus Leifsonia. Interestingly, phylogenetic analysis based on neighbour joining, minimum evolution and maximum parsimony (DNAPARS) algorithms indicated that the genus Leifsonia is polyphyletic, with the species clustering into three clades (Fig. 1). Despite the polyphyletic nature of the genus, all of the species share common generic characteristics, thus overcoming the ambiguity caused by the phylogenetic analyses. Of all the species of the genus Leifsonia, it was the type strain of the recently described species $L$. pindariensis (Reddy et al., 2008) with which KFC-22 ${ }^{\mathrm{T}}$ and SPC- $20^{\mathrm{T}}$ exhibited the highest 16S rRNA gene sequence similarity ( 97.7 and $97.3 \%$, respectively). This was further confirmed by phylogenetic analyses using minimum evolution and the unweighted pair group method with arithmetic averages, in which strains $\mathrm{KFC}-22^{\mathrm{T}}$ and SPC- $-20^{\mathrm{T}}$ clustered with $L$. pindariensis $\mathrm{PON} 10^{\mathrm{T}}$ at a bootstrap value greater than $50 \%$; with neighbour joining, the bootstrap value was $46 \%$. Phylogenetic trees constructed using Arthrobacter globiformis DSM 20124 ${ }^{\mathrm{T}}$ (GenBank accession no. X80736), Corynebacterium diphtheriae NCTC $11397^{\mathrm{T}}$ (X84248), Bacillus subtilis DSM $10^{\mathrm{T}}$ (AJ276351) and Agrococcus jenensis DSM $9580^{\mathrm{T}}$ (X92492) as outgroups showed no change in the topology of the trees (not shown). This suggests that the two isolates could be strains of previously described species. However, strains KFC- $22^{\mathrm{T}}$ and SPC- $20^{\mathrm{T}}$ showed DNA-DNA relatedness of 42 and $11 \%$, respectively, with $L$. pindariensis $\mathrm{PON} 10^{\mathrm{T}}$, clearly showing that both strains represent novel species. In addition, KFC- $22^{\mathrm{T}}$ and SPC $-20^{\mathrm{T}}$ exhibited phenotypic differences with respect to L. pindariensis $\mathrm{PON}^{\mathrm{T}}{ }^{\mathrm{T}}$ (Table 1). On the basis of the above characteristics, strains $\mathrm{KFC}-22^{\mathrm{T}}$ and $\mathrm{SPC}-20^{\mathrm{T}}$ represent novel species, for which the names Leifsonia kafniensis sp. nov. and Leifsonia antarctica sp. nov., respectively, are proposed. 
Table 1. Characteristics that serve to distinguish strains KFC$22^{\top}$ and $\mathrm{SPC}-20^{\top}$ from $L$. pindariensis PON $10^{\top}$

Data for L. pindariensis $\mathrm{PON} 10^{\mathrm{T}}$ are from Reddy et al. (2008). -, Absent; +, present; ND, not done; s, sensitive; R, resistant.

\begin{tabular}{|c|c|c|c|}
\hline Characteristic & $\begin{array}{c}\text { Strain } \\
\text { SPC-20 }^{T}\end{array}$ & 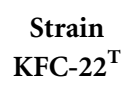 & $\begin{array}{l}\text { L. pindarien- } \\
\text { sis PON10 }\end{array}$ \\
\hline \multicolumn{4}{|c|}{ Temperature for growth $\left({ }^{\circ} \mathrm{C}\right)$} \\
\hline Range & $4-25$ & $4-30$ & $4-35$ \\
\hline Optimum & 22 & 22 & 25 \\
\hline \multicolumn{4}{|l|}{$\mathrm{pH}$ for growth } \\
\hline Range & $6.0-7.5$ & $6.5-7.5$ & $5.0-8.0$ \\
\hline Optimum & 7.5 & 7.5 & 7.0 \\
\hline $\begin{array}{l}\text { Maximum } \mathrm{NaCl} \text { concen- } \\
\text { tration for growth }(\%)\end{array}$ & 5 & 5 & 4 \\
\hline Oxidase & + & - & - \\
\hline Urease & - & - & + \\
\hline Gelatinase & + & - & - \\
\hline$\beta$-Galactosidase & + & - & + \\
\hline Citrate utilization & + & + & - \\
\hline Phosphatase & + & - & - \\
\hline Nitrate reduction & + & - & - \\
\hline Malonate utilization & - & + & ND \\
\hline \multicolumn{4}{|l|}{ Utilization of amino acids } \\
\hline L-Arginine & - & + & + \\
\hline L-Asparagine & - & + & + \\
\hline L-Aspartic acid & - & + & - \\
\hline L-Cysteine & + & - & + \\
\hline L-Glutamic acid & - & + & $\mathrm{ND}$ \\
\hline L-Isoleucine & + & + & - \\
\hline L-Lysine & + & + & - \\
\hline L-Serine & - & + & - \\
\hline L-Threonine & + & - & - \\
\hline L-Tyrosine & + & - & - \\
\hline L-Valine & - & + & + \\
\hline \multicolumn{4}{|l|}{ Production of acid from: } \\
\hline D-Arabinose & - & + & - \\
\hline L-Arabinose & + & - & ND \\
\hline Dulcitol & + & - & ND \\
\hline Erythritol & + & - & ND \\
\hline D-Fructose & + & + & - \\
\hline Lactose & + & - & $\mathrm{ND}$ \\
\hline Maltose & - & - & + \\
\hline D-Mannose & + & - & + \\
\hline D-Ribose & + & - & $\mathrm{ND}$ \\
\hline Trehalose & + & - & ND \\
\hline \multicolumn{4}{|l|}{ Carbon-source utilization } \\
\hline $\begin{array}{l}N \text {-Acetyl-D-glucosa- } \\
\text { mine }\end{array}$ & + & - & - \\
\hline Glucose & + & - & - \\
\hline Dulcitol & - & + & + \\
\hline Erythritol & + & - & + \\
\hline D-Fructose & + & + & - \\
\hline D-Galactose & + & + & - \\
\hline Inulin & - & - & + \\
\hline D-Lactose & - & - & + \\
\hline Maltose & - & - & + \\
\hline Mannitol & + & - & - \\
\hline Melibiose & - & - & + \\
\hline
\end{tabular}

Table 1. cont.

\begin{tabular}{|c|c|c|c|}
\hline Characteristic & $\begin{array}{c}\text { Strain } \\
\text { SPC-20 }^{\mathrm{T}}\end{array}$ & $\begin{array}{c}\text { Strain } \\
\text { KFC-22 }^{\mathrm{T}}\end{array}$ & $\begin{array}{l}\text { L. pindarien- } \\
\text { sis } \mathrm{PON} 10^{\mathrm{T}}\end{array}$ \\
\hline Raffinose & - & + & - \\
\hline D-Rhamnose & + & + & - \\
\hline Salicin & - & + & + \\
\hline L-Sorbose & - & - & + \\
\hline Xylitol & - & + & - \\
\hline \multicolumn{4}{|l|}{$\begin{array}{l}\text { Sensitivity to antibiotics } \\
\text { (per disc) }\end{array}$} \\
\hline Amikacin $(30 \mu \mathrm{g})$ & $\mathrm{R}$ & s & $\mathrm{s}$ \\
\hline Ampicillin $(10 \mu \mathrm{g})$ & s & $\mathrm{R}$ & s \\
\hline Cefoperazone $(75 \mu \mathrm{g})$ & $\mathrm{R}$ & s & s \\
\hline Lincomycin $(2 \mu \mathrm{g})$ & s & $\mathrm{R}$ & $\mathrm{ND}$ \\
\hline Nalidixic acid $(30 \mu \mathrm{g})$ & s & $\mathrm{R}$ & $\mathrm{R}$ \\
\hline $\begin{array}{l}\text { Nitrofurantoin } \\
(300 \mu \mathrm{g})\end{array}$ & $\mathrm{R}$ & S & s \\
\hline Novobiocin $(30 \mu \mathrm{g})$ & S & $\mathrm{R}$ & S \\
\hline Norfloxacin $(10 \mu \mathrm{g})$ & s & $\mathrm{R}$ & $\mathrm{R}$ \\
\hline Polymyxin B (50 U) & $\mathrm{R}$ & s & $\mathrm{R}$ \\
\hline Tobramycin $(10 \mu \mathrm{g})$ & $\mathrm{R}$ & S & $\mathrm{R}$ \\
\hline Menaquinones $^{\star}$ & $\begin{array}{c}\text { MK-10, MK- } \\
11\end{array}$ & $\begin{array}{l}\text { MK-11, } \\
\text { MK-12 }\end{array}$ & $\begin{array}{c}\text { (MK-9), MK- } \\
\text { 10, MK-11 }\end{array}$ \\
\hline Polar lipids $\dagger$ & $\begin{array}{c}\text { PE, PG, } \\
\text { DPG, 3ULs }\end{array}$ & $\begin{array}{l}\text { PE, PG, } \\
\text { DPG, PA }\end{array}$ & $\begin{array}{c}\text { PG, DPG, } \\
\text { (UL) }\end{array}$ \\
\hline Cell-wall sugars $\ddagger$ & $\begin{array}{l}\text { Gal, (Man, } \\
\text { Rha, US) }\end{array}$ & $\begin{array}{l}\text { Rha, Man, } \\
\text { Glc }\end{array}$ & $\begin{array}{l}\text { Rha, (Glc, } \\
\text { Gal, Man) }\end{array}$ \\
\hline \multicolumn{4}{|l|}{ Fatty acids (\%) } \\
\hline iso- $\mathrm{C}_{15: 0}$ & 6.62 & 3.15 & 5.6 \\
\hline anteiso- $\mathrm{C}_{15: 0}$ & 30.26 & 58.21 & 54.3 \\
\hline anteiso- $\mathrm{C}_{15: 1}$ & 9.37 & 2.20 & - \\
\hline $\mathrm{C}_{16: 0}$ & 1.86 & 1.55 & 1.9 \\
\hline iso- $\mathrm{C}_{16: 0}$ & 11.38 & 8.99 & 6.8 \\
\hline anteiso- $C_{16: 0}$ & 0.92 & - & - \\
\hline iso- $\mathrm{C}_{16: 1}$ & 0.50 & - & - \\
\hline $\mathrm{C}_{17: 0}$ & 2.75 & - & - \\
\hline $\mathrm{C}_{17: 0}$ cyclo & 1.72 & - & - \\
\hline iso- $\mathrm{C}_{17: 0}$ & 2.51 & 1.25 & - \\
\hline anteiso- $\mathrm{C}_{17: 0}$ & 10.88 & 22.36 & 19.1 \\
\hline anteiso- $\mathrm{C}_{17: 1}$ & 1.57 & - & - \\
\hline $\mathrm{C}_{17: 0} 2-\mathrm{OH}$ & 1.33 & - & - \\
\hline $\mathrm{C}_{18: 0}$ & 1.46 & - & - \\
\hline iso- $\mathrm{C}_{18: 1} \mathrm{H}$ & 2.76 & - & - \\
\hline
\end{tabular}

${ }^{*}$ Minor components given in parentheses.

$\dagger$ DPG, Diphosphatidylglycerol; PA, phosphatidic acid; PE, phosphatidylethanolamine; PG, phosphatidylglycerol; UL, unknown lipid. Minor components given in parentheses.

¥Gal, Galactose; Glc, glucose; Man, mannose; Rha, rhamnose; US, unknown sugar. Minor or trace components are given in parentheses.

\section{Description of Leifsonia kafniensis sp. nov.}

Leifsonia kafniensis (kaf.ni.en'sis. N.L. fem. adj. kafniensis pertaining to the Kafni glacier in the Himalayas of India, where the type strain was isolated). 


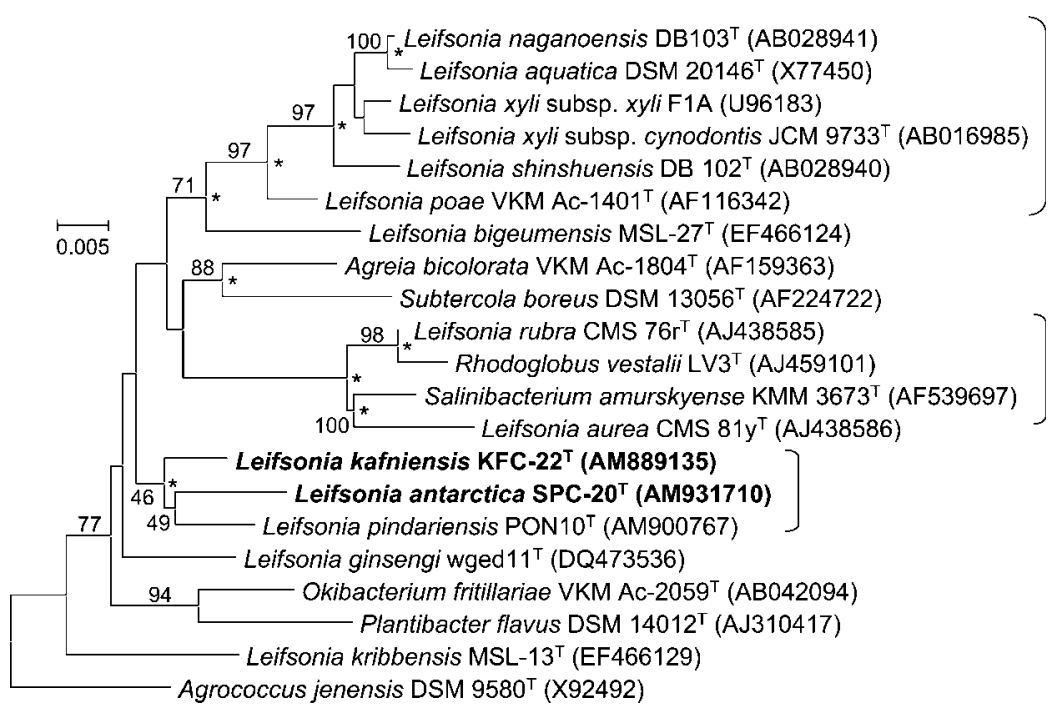

Fig. 1. Neighbour-joining phylogenetic tree, based on 16S rRNA gene sequences, showing the relationships between strains $\mathrm{KFC}-22^{\top}$ and $\mathrm{SPC}-2 \mathrm{O}^{\top}$ and related taxa. Bootstrap percentages (based on 1000 replications) greater than $40 \%$ are given at nodes. Asterisks indicate branches that were conserved in the trees constructed using neighbour joining, minimum evolution and maximum parsimony (DNAPARS). The three clades containing Leifsonia strains are indicated. Bar, 5 substitutions per 1000 nucleotide positions.

Cells are Gram-positive, non-motile, aerobic, rod-shaped $(0.4 \times 1.5 \mu \mathrm{m})$ and yellow-pigmented. Positive for catalase and aesculin hydrolysis, but negative for lipase, hydrolysis of casein and starch, $\mathrm{H}_{2} \mathrm{~S}$ production, lysine, arginine and ornithine decarboxylases, indole production, the methyl red test, the Voges-Proskauer test and for phenylalanine deamination. Does not produce acid from myo-inositol, Drhamnose or D-xylose. Utilizes glycerol, but not creatinine, L-histidine, hydroxyproline, L-leucine, L-methionine, sucrose, trehalose, L-tryptophan or D-xylose. The type strain is sensitive to the following antibiotics ( $\mu \mathrm{g}$ per disc): bacitracin (10), carbenicillin (100), cefotaxime (30), chloramphenicol (30), erythromycin (15), gentamicin G (30), oleandomycin (15), penicillin G (10), rifampicin (30), spectinomycin (100), streptomycin (10) and tetracycline (30); resistant to colistin (10 $\mu \mathrm{g}$ per disc). Absorption maxima of the yellow pigment in methanol at 360, 370, 440, 450, 470 and $480 \mathrm{~nm}$. The other characteristics of the species are listed in Table 1.

The type strain, KFC- $22^{\mathrm{T}} \quad\left(=\mathrm{NCCB} 100216^{\mathrm{T}}=\mathrm{LMG}\right.$ $24362^{\mathrm{T}}$ ), was isolated from a soil sample collected close to the Kafni glacier in the Himalayan mountain ranges of India.

\section{Description of Leifsonia antarctica sp. nov.}

Leifsonia antarctica (an.tarc'ti.ca. L. fem. adj. antarctica southern, by extension pertaining to the Antarctic, where the type strain was isolated).

Cells are Gram-positive, non-motile, aerobic, rod-shaped $(0.5 \times 0.7 \mu \mathrm{m})$ and pale-yellow-pigmented. Positive for catalase and aesculin hydrolysis, but negative for lipase, hydrolysis of casein and starch, $\mathrm{H}_{2} \mathrm{~S}$ production, lysine, arginine and ornithine decarboxylase, indole production, in the methyl red test, in the Voges-Proskauer test and for phenylalanine deamination. Does not produce acid from myo-inositol, D-rhamnose or D-xylose. Utilizes glycerol, but not creatinine, L-histidine, hydroxyproline, L-leucine, L-methionine, sucrose, trehalose, L-tryptophan or D-xylose.
The type strain is sensitive to the following antibiotics ( $\mu \mathrm{g}$ per disc): bacitracin (10), carbenicillin (100), cefotaxime (30), chloramphenicol (30), erythromycin (15), gentamicin-G (30), oleandomycin (15), penicillin G (10), rifampicin (30), spectinomycin (100), streptomycin (10) and tetracycline (30); resistant to colistin (10 $\mu \mathrm{g}$ per disc). Contains three unknown lipids, with $R_{\mathrm{f}}$ values of $0.63,0.66$ and 0.73 , in addition to the lipids listed in Table 1 . The other characteristics of the species are listed in Table 1. Absorption maxima of the yellow pigment in methanol at $350,360,370,430,440,450,470$ and $475 \mathrm{~nm}$.

The type strain, SPC- $20^{\mathrm{T}} \quad\left(=\mathrm{NCCB} \quad 100227^{\mathrm{T}}=\mathrm{LMG}\right.$ $24541^{\mathrm{T}}$ ), was isolated from a sediment from the Antarctic Ocean, near the Larsemann Hill area of Antarctica.

\section{Acknowledgements}

We would like to thank the Department of Biotechnology, the Department of Earth Sciences and The National Centre for Antarctic Research, Government of India, for financial support to S. S.

\section{References}

Behrendt, U., Ulrich, A., Schumann, P., Naumann, D. \& Suzuki, K. (2002). Diversity of grass-associated Microbacteriaceae isolated from the phyllosphere and litter layer after mulching the sward; a polyphasic characterization of Subtercola pratensis sp. nov., Curtobacterium herbarum sp. nov. and Plantibacter flavus gen. nov., sp. nov. Int J Syst Evol Microbiol 52, 1441-1454.

Collins, M. D., Pirouz, T., Goodfellow, M. \& Minnikin, D. E. (1977). Distribution of menaquinones in actinomycetes and corynebacteria. J Gen Microbiol 100, 221-230.

Dastager, S. G., Lee, J. C., Ju, Y. J., Park, D. J. \& Kim, C. J. (2008). Leifsonia bigeumensis sp. nov., isolated from soil in Bigeum Island, Korea. Int J Syst Evol Microbiol 58, 1935-1938.

Dastager, S. G., Lee, J. C., Ju, Y. J., Park, D. J. \& Kim, C. J. (2009). Leifsonia kribbensis sp. nov., isolated from soil. Int J Syst Evol Microbiol 59, 18-21. 
Davis, M. J., Gillaspie, A. G., Jr, Vidaver, A. K. \& Harris, R. W. (1984). Clavibacter: a new genus containing some phytopathogenic coryneform bacteria, including Clavibacter xyli subsp. xyli sp. nov., subsp. nov. and Clavibacter xyli subsp cynodontis subsp. nov., pathogens that cause ratoon stunting disease of sugarcane and burmudagrass stunting disease. Int J Syst Bacteriol 34, 107-117.

Evtushenko, L. I., Dorofeeva, L. V., Subbotin, S. A., Cole, J. R. \& Tiedje, J. M. (2000). Leifsonia poae gen. nov., sp. nov., isolated from nematode galls on Poa annua, and reclassification of 'Corynebacterium aquaticum' Leifson 1962 as Leifsonia aquatica (ex Leifson 1962) gen. nov., nom. rev., comb. nov. and Clavibacter xyli Davis et al. 1984 with two subspecies as Leifsonia xyli (Davis et al. 1984) gen. nov., comb. nov. Int J Syst Evol Microbiol 50, 371-380.

Evtushenko, L. I., Dorofeeva, L. V., Dobrovolskaya, T. G., Streshinskaya, G. M., Subbotin, S. A. \& Tiedje, J. M. (2001). Agreia bicolorata gen. nov., sp. nov., to accommodate actinobacteria isolated from narrow reed grass infected by the nematode Heteroanguina graminophila. Int J Syst Evol Microbiol 51, 2073-2079.

Evtushenko, L. I., Dorofeeva, L. V., Krausova, V. I., Gavrish, E. Y., Yashina, S. G. \& Takeuchi, M. (2002). Okibacterium fritillariae gen. nov., sp. nov., a novel genus of the family Microbacteriaceae. Int J Syst Evol Microbiol 52, 987-993.

Groth, I., Schumann, P., Weiss, N., Martin, K. \& Rainey, F. A. (1996). Agrococcus jenensis gen. nov., sp. nov., a new genus of actinomycetes with diaminobutyric acid in the cell wall. Int J Syst Bacteriol 46, 234239.

Han, S. K., Nedashkovskaya, O. I., Mikhailov, V. V., Kim, S. B. \& Bae, K. S. (2003). Salinibacterium amurskyense gen. nov., sp. nov., a novel genus of the family Microbacteriaceae from the marine environment. Int J Syst Evol Microbiol 53, 2061-2066.

Kimura, M. (1980). A simple method for estimating evolutionary rates of base substitutions through comparative studies of nucleotide sequences. J Mol Evol 16, 111-120.

Komagata, K. \& Suzuki, K. (1987). Lipid and cell-wall analysis in bacterial systematics. Methods Microbiol 19, 161-207.

Kumar, S., Tamura, K. \& Nei, M. (2004). MEGA3: integrated software for molecular evolutionary genetics analysis and sequence alignment. Brief Bioinform 5, 150-163.

Lányí, B. (1987). Classical and rapid identification methods for medically important bacteria. Methods Microbiol 19, 1-67.

Leifson, E. (1962). The bacterial flora of distilled and stored water. III. New species of the genera Corynebacterium, Flavobacterium, Spirillum and Pseudomonas. Int Bull Bacteriol Nomencl Taxon 12, 161-170.

Männistö, M. K., Schumann, P., Rainey, F. A., Kämpfer, P., Tsitko, I., Tiirola, M. A. \& Salkinoja-Salonen, M. S. (2000). Subtercola boreus gen. nov., sp. nov. and Subtercola frigoramans sp. nov., two new psychrophilic actinobacteria isolated from boreal groundwater. Int $J$ Syst Evol Microbiol 50, 1731-1739.

Marmur, J. (1961). A procedure for the isolation of deoxyribonucleic acid from microorganisms. J Mol Biol 3, 208-218.

Qiu, F., Huang, Y., Sun, L., Zhang, X., Liu, Z. \& Song, W. (2007). Leifsonia ginsengi sp. nov., isolated from ginseng root. Int J Syst Evol Microbiol 57, 405-408.
Reddy, G. S. N., Aggarwal, R. K., Matsumoto, G. I. \& Shivaji, S. (2000). Arthrobacter flavus sp. nov., a psychrophilic bacterium isolated from a pond in McMurdo Dry Valley, Antarctica. Int J Syst Evol Microbiol 50, 1553-1561.

Reddy, G. S. N., Prakash, J. S. S., Srinivas, R., Matsumoto, G. I. \& Shivaji, S. (2003). Leifsonia rubra sp. nov. and Leifsonia aurea sp. nov., psychrophiles from a pond in Antarctica. Int $J$ Syst Evol Microbiol 53, 977-984.

Reddy, G. S. N., Matsumoto, G. I., Schumann, P., Stackebrandt, E. \& Shivaji, S. (2004). Psychrophilic pseudomonads from Antarctica: Pseudomonas antarctica sp. nov., Pseudomonas meridiana sp. nov. and Pseudomonas proteolytica sp. nov. Int J Syst Evol Microbiol 54, 713719.

Reddy, G. S. N., Nagy, M. \& Garcia-Pichel, F. (2006). Belnapia moabensis gen. nov., sp. nov., an alphaproteobacterium from biological soil crusts in the Colorado Plateau, USA. Int J Syst Evol Microbiol 56, 51-58.

Reddy, G. S. N., Potrafka, R. M. \& Garcia-Pichel, F. (2007). Modestobacter versicolor sp. nov., an actinobacterium from biological soil crusts that produces melanins under oligotrophy, with emended descriptions of the genus Modestobacter and Modestobacter multiseptatus Mevs et al. 2000. Int J Syst Evol Microbiol 57, 2014-2020.

Reddy, G. S. N., Prabagaran, S. R. \& Shivaji, S. (2008). Leifsonia pindariensis sp. nov., isolated from the Pindari glacier of the Indian Himalayas, and emended description of the genus Leifsonia. Int J Syst Evol Microbiol 58, 2229-2234.

Sheridan, P. P., Loveland-Curtze, J., Miteva, V. I. \& Brenchley, J. E. (2003). Rhodoglobus vestalii gen. nov., sp. nov., a novel psychrophilic organism isolated from an Antarctic Dry Valley lake. Int J Syst Evol Microbiol 53, 985-994.

Shivaji, S., Chaturvedi, P., Reddy, G. S. N. \& Suresh, K. (2005). Pedobacter himalayensis sp. nov., from the Hamta glacier located in the Himalayan mountain ranges of India. Int J Syst Evol Microbiol 55, 1083-1088.

Smibert, R. M. \& Krieg, N. R. (1994). Phenotypic characterization. In Methods for General and Molecular Bacteriology, pp. 607-654. Edited by P. Gerhardt, R. G. E. Murray, W. A. Wood \& N. R. Krieg. Washington, DC: American Society for Microbiology.

Suzuki, K., Suzuki, M., Sasaki, J., Park, Y. H. \& Komagata, K. K. (1999). Leifsonia gen. nov., a genus for 2,4-diaminobutyric acidcontaining actinomycetes to accommodate "Corynebacterium aquaticum" Leifson 1962 and Clavibacter xyli subsp. cynodontis Davis et al. 1984. J Gen Appl Microbiol 45, 253-262.

Tamaoka, J. (1986). Analysis of bacterial menaquinone mixtures by reverse-phase high-performance liquid chromatography. Methods Enzymol 123, 251-256.

Tamaoka, J., Katayama-Fujimura, Y. \& Kuraishi, H. (1983). Analysis of bacterial menaquinone mixture by high performance liquid chromatography. J Appl Bacteriol 54, 31-36.

Thompson, J. D., Higgins, D. G. \& Gibson, T. J. (1994). CLUSTAL W: improving the sensitivity of progressive multiple sequence alignment through sequence weighting, position-specific gap penalties and weight matrix choice. Nucleic Acids Res 22, 4673-4680. 